\title{
Biological Control of the Greenhouse White-Fly.
}

By E. R. SPExer, Entomologist to the Experimental and Research Station, Cheshunt.

TTHE greenhouse white-fly is a pest of a number of plants grown under glass, and has, during the past fifteen years, become so widely distributed in Great Britain, Ireland, and the Channel Islands that the owner of the smallest conservatory must by this time be familiar with it and with the sordid appearance of his plants when infested by this insect.

Through the researches of Dr. Ll. Lloyd at the Cheshunt Experimental Station in 1920, it was shown that the pest could be controlled in commercial tomato and cucumber nurseries by fumigation either with the cheap ' cyanide' process or with the vapour of the more expensive liquid, tetrachlorethane. His demonstration of the correct methods of fumigating so as to reduce injury to the tomato plant to a minimum resulted in an incalculable saving to the industry.

In spite of the comparatively widespread use of these fumigants, the general white-fly population continued to increase in subsequent years, the commercial grower began to realise certain difficulties connected with extensive fumigation, and certain varieties of greenhouse plants were found to be very seriously injured by the vapour of tetrachlorethane.

The appearance of a parasite enemy of white-fly in Surrey was recorded by the late Prof. H. MaxwellLefroy, but the habit of this particular species, which still exists in England, does not admit of its exercising any material measure of control over the pest. An allied hymenopterous parasite, Encarsia formosa, was found by Mr. L. Hawkins at Elstree, Herts, in 1926, and scales of white-fly, parasitised by this insect, were received at the Cheshunt Experimental Station through the Gardeners' Chronicle. Observations upon the habits of the parasite established the facts that it reproduces itself parthenogenetically; is capable of distributing itself quickly by flight not only within an area covered by glass, but in midsummer for distances of several miles over land interspersed with greenhouses; and that a complete control of white-fly infestation is obtained by it when warm temperatures prevail.

Anything approaching extermination of the pest within a short period of time could not be expected, as the parasite is entirely dependent upon the young stages of white-fly for its existence, and cannot survive the winter either out-of-doors or in unheated greenhouses. However, the results of distribution during the summer of 1927 were so promising, that an application was made to the Empire Marketing Board, which generously gave a grant for the erection of a glasshouse in which the parasite could be propagated upon a larger scale.

During the earlier investigations upon the breeding habits of the parasite, an important fact came to light, namely, that the percentage parasitisation of white-fly seales is not the same upon all types of plant. The tobacco plant in particular, when grown in small pots, produces a sticky foliage upon which the white-fly breeds readily, but to which the parasite shows some aversion. It is due to this fortunate circumstance that a stock of white-fly can be maintained so that a continuous supply of parasitised scales upon other plants is obtainable.

The method of distribution is simple and has been adhered to as being the best with which to establish the parasite in greenhouses. Tomato plants are grown in pots or in the ground; tobacco pot-plants infested with white-fly and with a certain number of parasitised scales upon them are introduced amongst the former. The white-fly soon distribute themselves and lay eggs upon the lowest branches of the tomato plants; the scales which result from these eggs readily become parasitised and are recognisable by the jet-black colour which they assume 11-14 days after each has received a parasite egg. This blackening marks the time at which the pupal white-fly is destroyed by the larva of the parasite within the scale-case. When a large number of black scales have made their appearance, the low branches are removed, packed in boxes, and sent out to the grower, who ties them into small bunches and hangs them about in his infested house for a period of three weeks, during which time the parasite larva pupates and finally emerges, through a hole which it cuts in the roof of the scale-case, as the adult winged parasite, which immediately begins to deposit eggs in whitefly scales in its new environment.

In the meantime, more white-fly have bred upon the now lowest branches of the original tomato plants, which are afterwards used as another supply for distribution, and so on. A single series of tomato plants will thus yield a continuous supply of parasites for several months if transferred to 12 -inch pots when young or when grown in the ground. At least a thousand parasitised scales may be present upon a single tomato branch, and each parasite eventually emerging is capable of causing the subsequent destruction of some fifty white-fly scales.

Male parasites appear rarely and usually only when temperatures have fallen below $60^{\circ} \mathrm{F}$. over a period of some weeks. Under such conditions the fertility of the female may be much reduced. Adults of both sexes measure rather less than $\frac{1}{40}$ in. in length, so that they are not readily noticed unless very large numbers are present.

The approximate number of parasitised scales distributed in this way to growers of glasshouse plants during the past four years may be of interest:

\begin{tabular}{|c|c|c|c|}
\hline Year. & $\begin{array}{l}\text { Approx. No. } \\
\text { Distributed. }\end{array}$ & $\begin{array}{l}\text { Recip- } \\
\text { ients. }\end{array}$ & Localities. \\
\hline 1927 & 15,000 & 13 & 5 English, 1 Welsh County. \\
\hline 1928 & $\begin{array}{r}200,000 \\
20,000 \\
20,000 \\
10,000\end{array}$ & $\begin{array}{l}92 \\
\cdots \\
\cdots \\
\cdots\end{array}$ & $\begin{array}{l}20 \text { Counties, England and } \\
\text { Wales. } \\
\text { Royal Botanic Gardens, Kew. } \\
\text { Canada. } \\
\text { Channel Islands. }\end{array}$ \\
\hline Total & 250,000 & . & . \\
\hline 1929 & $\begin{array}{r}900,000 \\
20,000 \\
30,000 \\
20,000 \\
100,000\end{array}$ & $\begin{array}{r}509 \\
28 \\
14 \\
11 \\
16\end{array}$ & $\begin{array}{l}40 \text { English Counties. } \\
\text { Wales. } \\
\text { Scotland. } \\
\text { Ireland. } \\
\text { Channel Islands. }\end{array}$ \\
\hline Total & $1,070,000$ & 578 & \\
\hline 1930 & $\begin{array}{r}1,350,000 \\
40,000 \\
50,000 \\
10,000 \\
50,000\end{array}$ & $\begin{array}{r}745 \\
38 \\
16 \\
6 \\
22\end{array}$ & $\begin{array}{l}42 \text { English Counties. } \\
\text { Wales. } \\
\text { Scotland. } \\
\text { Ireland. } \\
\text { Channel Islands. }\end{array}$ \\
\hline Total & $1,500,000$ & 827 & \\
\hline
\end{tabular}

Up to May 1930, boxes of parasites were distributed to applicants free of charge, but afterwards a charge had to be made to defray the cost of packing, etc., except to members and associates of the Nursery and Market Gardens Industries Development Society, Ltd., which controls the Cheshunt Experimental

No. 3191, VoL. 126] 
Station. After this system was adopted, the number of applications fell off, so that the supply of parasites available exceeded the demand.

In 1928 reports were received from the majority of the recipients as to the measure of control which the parasite had effected. Apart from a negligible number of cases in which the parasite failed to establish itself, about half reported complete and the rest partial control. Owing to the numbers supplied, it was impossible to obtain similar information in later years, but many reports of complete control have come to hand from all quarters.

The working of the parasite is best judged of from tomato-houses in the Lea Valley, in some parts of which the pest has been extremely severe for many years. In these particular areas, it has been found unnecessary to make use of fumigants during both the last and the current year.

The very large number of parasites which continually escape from the breeding house at Cheshunt appear to have furthered the distribution of the beneficial insect throughout glasshouses in Hertfordshire, and the white-fly population of that county, in which there is almost as great an area of glasshouses as in the whole of the rest of Great Britain, has definitely been reduced to a small fraction of what it was five years ago.
Applications for white-fly parasites should be made to the Experimental and Research Station, Cheshunt, Herts, not later in the year than September, nor earlier than March, unless minimum night temperatures of $55^{\circ} \mathrm{F}$. can be maintained in the greenhouse during the winter months. Particulars of charges, etc., will be forwarded immediately to applicants.

It is useless to introduce the parasite into greenhouses in which the white-fly is not breeding at the time of receipt of parasite material. The parasite is quite harmless to vegetation and to animals, and does not parasitise insects other than the white-fly. In cases of severe infestation, when immediate control of white-fly is demanded, the greenhouse may be fumigated with a half dosage of 'cyanide' or tetrachlorethane without injury to the parasite, which is also not materially affected by other fumigants and sprays generally used for the control of pests upon living glasshouse plants, with the possible exception of paraffin emulsion.

An illustrated account of the white-fly and its parasite was published in the Journal of the Royal Horticultural Society, vol. 54, part 1, p. 181, January 1929 , and a detailed account of the life-history of Encarsia formosa appeared in the Bulletin of Entomo. logical Research, vol. 18, pt. 3, p. 301, March 1927.

\section{Current Mortality Rates.}

THE recent inaugural addresses by $\mathrm{Mr}$. $\mathrm{H}$. M. Trouncer at the Institute of Actuaries in London and by Mr. Steuart E. Macnaghten at the Faculty of Actuaries in Edinburgh, besides dealing with certain technical matters, discussed subjects of more general scientific interest, and directed attention to the great decrease in the rates of mortality between ages 20 years and 70 years in the general population, and presumably also among the lives assured by the various companies in Great Britain.

Mr. Trouncer mentioned that it is common knowledge to insurance offices that investigate their own experience, that, apart from yearly fluctuations, the rates of mortality are now lighter than ever before. The two actuarial societies have in hand a new continuous investigation into the mortality experience of assured lives and annuitants, and while results with regard to the latter have already been published, with forecasts of future mortality and extensive tables, the work on assured lives has taken longer to arrange and the results for the three years 1924-26 will only be fully available early next year, but will be quickly followed by a further three years' experience. This last point is important, as there might be a danger in using the figures of three such light mortality years as 1924-26.

Mr. Macnaghten referred also to research into the effect of family and personal history and occupation and foreign residence on mortality and sickness, and reminded his audience that, a few years before the War, Mr. Lewis P. Orr delivered a valuable address on this subject and advocated that a bureau of research should be set up. The idea was received favourably and we have reason to believe that a scheme was actually worked out in a preliminary way and put before the insurance offices. Then the War came and all such work had to be put aside. In spite of various post-War difficulties, much has already been done to bring mortality statistics up-to-date, and it remains for the future to show how far the work can be extended to special classes of risk, as has been possible in the United States, where the War interfered less.

It would seem that an investigation into the mortality of assured persons who proceed to tropical or sub-tropical areas is required, and there is no doubt that the information at present available is incom. plete and untrustworthy, though individual actuaries have done something to fill the gap, as, for example, Mr. H. E. Raynes, for East and West Africa. The risk in all such cases has decreased : mainly owing to the great advances in tropical hygiene and preventive medicine, though a little of the apparent improvement may be attributed to a wiser choice of the men sent abroad.

Mr. Macnaghten amused his audience by an example of the change in point of view. "It is difficult", he said, "to realise to-day that eighty years ago lives resident in the United States west of the Mississippi were not accepted for life assurance except on almost prohibitive terms." With a further improvement in conditions, with greater knowledge of how to live in unhealthy areas, and with accurate statistics to measure the risk, it is to be hoped that those who look back in future years will notice similar changes.

\section{The British Industries Fair.}

I'HE Committee which was appointed by the 1 President of the Board of Trade in February 1930, under Lord Chelmsford as chairman, to examine the present situation of the British Industries Fair and to consider means of increasing its utility to British trade, in its report (London : H.M.S.O. Cmd. 3726. Price $6 d$. net) makes the basic recommenda- tion that " the Fair should be developed so as to become a truly national manifestation of the quality and range of British products and an increasingly powerful factor in the expansion of our trade" Both Government and manufacturers generally should accord it more vigorous support, and the public should be encouraged to learn through the Fair that British

No. 3191, VoL. 126] 